\title{
Pengaruh Penggunaan Teknologi Informasi, Efektivitas Sistem Informasi Akuntansi, dan Sistem Pengendalian Intern Terhadap Kinerja Karyawan
}

\author{
Putu Diah Mirnasari ${ }^{1}$ \\ I Made Sadha Suardhika
}

${ }^{1}$ Fakultas Ekonomi dan Bisnis Universitas Udayana, Bali, Indonesia
email: diamirnasari@ gmail.com/Telp : 085792422018
${ }^{2}$ Fakultas Ekonomi dan Bisnis Universitas Udayana, Bali, Indonesia

\begin{abstract}
ABSTRAK
Penelitian ini bertujuan untuk mengetahui pengaruh penggunaan teknologi informasi, efektivitas sistem informasi akuntansi, dan sistem pengendalian intern terhadap kinerja karyawan. Penelitian ini dilakukan pada pada Bank Perkreditan Rakyat di Kota Denpasar. Dalam penelitian ini menggunakan teknik sampling jenuh. Responden dalam penelitian ini sebanyak 75 karyawan yang menggunakan komputer dalam mengerjakan tugasnya. Data dalam penelitian ini diperoleh melalui observasi, wawancara dan kuesioner. Teknik analisis yang digunakan adalah teknik analisis regresi linear berganda dan uji t yang sebelumnya dilakukan pengujian instrumen penelitian antara lain uji validitas, reliabilitas dan uji asumsi klasik.Berdasarkan hasil penelitian, diketahui bahwa variabel penggunaan teknologi informasi $\left(\mathrm{X}_{1}\right)$, efektivitas sistem informasi akuntansi $\left(\mathrm{X}_{2}\right)$, dan sistem pengendalian intern $\left(\mathrm{X}_{3}\right)$ secara keseluruhan berpengaruh positif terhadap kinerja karyawan (Y).Penelitian ini diharapkan dapat memberikan wawasan dalam penggunaan teknologi informasi, efektivitas sistem informasi akuntansi dan sisem pengendalian intern terhadap kinerja karyawan serta akan memberikan kontribusi positif bagi semua pihak khususnya bagi perusahaan.

Kata Kunci: Teknologi informasi, efektivitas sistem informasi, pengendalian intern, kinerja karyawan.
\end{abstract}

\begin{abstract}
This research was conducted at the Rural Bank in Denpasar City. In this research use saturated sampling technique. Respondents in this study as many as 75 employees who use computers in doing their work. The data in this research is obtained through observation, interview and questionnaire. Analytical techniques used are multiple linear regression analysis techniques and test previously conducted testing of research instruments such as validity test, reliability and classical assumption test. Based on the result of research, it is known that the variable of information technology usage (X1), effectiveness of accounting information system (X2), and internal control system (X3) as a whole have positive effect on employee performance $(Y)$. This study is expected to provide insight into the use of information technology, the effectiveness of accounting information systems and internal control systems on employee performance and will contribute positively to all parties, especially for the company.

Keywords: Information technology, effectiveness of information system, internal control, employee performance.
\end{abstract}

\section{PENDAHULUAN}

Teknologi informasi dapat dimanfaatkan secara efektif sehingga dapat memberikan kontribusi terhadap kinerja, maka anggota dalam organisasi harus menggunakan teknologi tersebut dengan baik. Teknologi tidak dapat dimanfaatkan dengan baik jika para pengguna teknologi memiliki kemampuan 
Putu Diah Mirnasari dan I Made Sadha Suardhika. Pengaruh...

terbatas dalam menggunakan teknologi tersebut. Kelemahan dasar individu seperti kelelahan dan kecermatan serta ketelitian dapat mempengaruhi hasil pekerjaan Dengan demikian, kompetensi individu dalam perusahaan pun perlu ditingkatkan, yaitu berupa kemampuan untuk mengoperasikan teknologi (Tjhai, 2003).

Penggunaan teknologi informasi untuk mendukung aktivitas operasional perusahaan bukan merupakan hal yang baru lagi, melainkan kebutuhan utama sebagai salah satu strategi bersaing pada era sekarang ini. Teknologi informasi terus berkembang salah satu hasil pengembangan teknologi informasi yang banyak dimanfaatkan oleh organisasi untuk menjalankan kegiatan operasionalnya adalah sistem informasi. Sistem informasi sebagai seperangkat komponen yang saling berhubungan, yang mengumpulkan (atau mendapatkan kembali), memproses, menyimpan, dan mendistribusikan informasi untuk mendukung pengambilan keputusan dan pengendalian dalam suatu organisasi. Salah satu sistem infromasi yang digunakan dalam perusahaan adalah sistem informasi akuntansi (Mulyadi, 2008).

Sistem informasi akuntansi merupakan salah satu pengembangan teknologi yang dioperasikan oleh sumber daya manusia dalam suatu organisasi yang bertugas menyiapkan keuangan dan juga informasi yang diperoleh dari kegiatan pengumpulan dan pengolahan transaksi (Marlinawati, 2013). Sistem informasi dapat meningkatkan keunggulan bersaing dalam perkembangan organisasi yang modern. Sistem informasi akuntansi akan mempengaruhi bagaimana perusahaan membuat keputusan, merencanakan, dan mengatur semua bagian di dalam perusahaan. Sistem informasi akuntansi memberi kesempatan 
bagi pembisnis untuk meningkatkan efisiensi dan efektivitas dalam pengambilan keputusan sehingga memungkinkan perusahaan mendapatkan keunggulan kompetitif (Mahendra, 2013).

Perkembangan sistem informasi akuntansi membawa perubahanperubahan yang terjadi pada individu atau badan usaha dengan dilihat pada kecenderungan untuk selalu menggunakan komputer dalam suatu aktifitas kegiatan usahanya hampir semua bidang pekerjaan diterapkan dalam suatu sistem komputerisasi, hal ini bertujuan untuk mengefektifkan kerja dan mengefisienkan waktu untuk meningkatkan keuntungan. Perkembangan sistem informasi akuntansi berdampak luas yang dapat dirasakan perusahaan berupa peningkatan kinerja, kemudahan dalam pembuatan laporan, dan informasi yang di dapat akan lebih akurat. Dampak negative dari perusahaan harus mengeluarkan dana yang cukup besar untuk memperoleh sebuah sistem informasi termasuk untuk perawatan serta perbaikan jika sistem informasi yang digunakan mengalami kerusakan.

Sistem Pengendalian Internal (SPI) juga memegang peranan penting bagi kelangsungan hidup perusahaan. Tercapainya pengendalian internal perusahaan yang baik tentu saja akan meningkatkan produktivitas serta kinerja para karyawan. Arti kinerja atau performance adalah hasil kerja yang dapat dicapai oleh seseorang atau sekelompok orang dalam suatu organisasi, sesuai dengan wewenang dan tanggung jawab masing-masing, dalam rangka upaya mencapai tujuan organisasi bersangkutan secara legal, tidak melanggar hukum dan sesuai dengan moral maupun etika. Pada masing-masing organisasi tentu saja 
Putu Diah Mirnasari dan I Made Sadha Suardhika. Pengaruh...

memerlukan sistem pengendalian intern. Hal tersebut bertujuan untuk mencegah atau mengurangi adanya kerugian. Jika pengabaian sistem pengendalian intern terjadi maka suatu organisasi harus siap menerima risiko kerugian dan cepat atau lambat dampak buruk akan terjadi pada organisasi (Suyadi dan Mariani, 2012).

Sistem pengendalian internal meliputi struktur organisasi, metode dan ukuran-ukuran yang dikoordinasikan untuk menjaga kekayaan organisasi, mengecek ketelitian dan keandalan data akuntansi, mendorong efesiensi dan mendorong dipatuhinya kebijakan manajemen (Mulyadi, 2001). Hal ini juga didukung dengan penelitian yang dilakukan Njeri (2014) yang mengkaji tentang pengaruh pengendalian internal terhadap kinerja di Kenya dan menemukan bahwa jika dalam organisasi, individu-individu yang memiliki sistem pengendalian internal yang kuat akan memiliki kinerja yang tinggi.

Bank Perkreditan Rakyat (BPR) merupakan lembaga keuangan mikro yang memiliki fungsi dan peran yang strategis dalam mendorong pertumbuhan usaha mikro, kecildan menengah (UMKM) serta sekaligus sebagai badan keuangan yang dapat melakukan pemberdayaan bagi pengusaha lokal sebagai bentuk nyata dari kegiatan ekonomi yang berbasis kerakyatan. BPR sebagai salah satu badan keuangan kini juga menerapkan teknologi dalam sistem informasi yang dimilikinya. Penggunaan teknologi informasi sangat membantu operasional bank dalam menampung seluruh informasi yang dibutuhkan agar dapat membuat keputusan secara akurat. BPR awalnya dibentuk dengan tujuan untuk membantu perekonomian masyarakat pedesaan terbebas dari bunga yang sangat tinggi. BPR merupakan lembaga perbankan resmi yang diatur berdasarkan Undang-undang 
No.7 tahun 1992 tentang Perbankan dan sebagaimana telah diubah dengan Undang-undang No.10 tahun 1998.

Fungsi Bank Perkreditan Rakyat (BPR) secara umum adalah sebagai badan usaha yang menghimpun dan menyalurkan dana masyarakat, harus mampu menunjang modernisasi pedesaan dan memberikan layanan jasa perbankan bagi golongan ekonomi lemah atau pengusaha kecil. Akan tetapi saat ini terdapat pesaing BPR yaitu lembaga keuangan mikro lainnya seperti gerai Pegadaian telah merambah sampai ke pedesaan yang memiliki prosedur dan layanan penyaluran kredit yang hampir sama dengan BPR yaitu cepat dan sederhana. Masalah seperti inilah yang dikhawatirkan dapat mengancam kelangsungan hidup BPR.

Dengan demikian BPR diharapkan mampu untuk melakukan pengembangan sistem informasi dan teknologi informasi serta memperbaiki kinerja individual karyawan untuk memiliki keunggulan kompetitif. Kinerja karyawan dapat mempengaruhi tingkat keberhasilan suatu pekerjaan karena dengan hasil yang dicapai tersebut kita dapat mengetahui seberapa besar hasil kinerja seorang karyawan.

BPR pada wilayah Denpasar dalam lima tahun terakhir menunjukkan peningkatan dari segi jumlah Kantor Cabang (KC) maupun kredit yang disalurkan pada masyarakat. Meningkatnya jumlah kantor disebabkan oleh salah satu faktor yaitu kepercayaan masayarakat yang meningkat menyebabkan diperlukannya perluasan kantor. Penyaluran kredit pun terus mengalami peningkatan yang berarti kinerja karyawan dalam mengolah dana bank dan memberikan informasi semakin mendapatkan kepercayaan. Disini mengharuskan BPR mengedepankan efisiensi 
Putu Diah Mirnasari dan I Made Sadha Suardhika. Pengaruh...

sistem informasi akuntansi menggunakan teknologi untuk mencegah terjadinya kredit bermasalah. Untuk mengoperasikan teknologi yang begitu canggih maka perusahaan perbankan harus mengetahui kemampuan sumber daya yang dimilikinya sumber daya yang dimaksud adalah kinerja karyawan.

Pada kenyataannya banyak permasalahan mendasar yang membuat BPR terhalang teknologi seperti lemahnya pengetahuan sumber daya manusia dalam mengoperasikan sistem informasi, kurangnya kepercayaan diri karyawan dalam menggunakan teknologi informasi, dan yang paling absurd adalah tidak tahu harus memulainya dari mana. Tanpa perencanaan sistem yang memadai, pengelolaan penggunaan teknologi informasi juga akan berjalan apa adanya, sementara risiko operasional atas pengamanan data transaksi/nasabah semakin meningkat, terlebih lagi risiko strategis dari perkembangan usaha serta persaingan bisnis.

Berdasarkan penelitian sebelumnya (Marlinawati, 2013) penggunaan teknologi informasi dan efektivitas sistem informasi akuntansi berpengaruh positif terhadap kinerja karyawan. Selain itu penelitian yang dilakukan oleh (Sugiartini, 2016) yang mengatakan bahwa efektivitas sistem informasi akuntansi berpengaruh positif terhadap kinerja individual. Senada dengan hal tersebut, (Salehi, dkk. 2010) yang mengatakan beberapa organisasi bisnis mendapatkan keunggulan kompetitif dengan melengkapi sistem informasinya, dengan demikian kinerja individual karyawan juga akan semakin efektif. Penelitian yang dilaukan oleh (Lasso, 2016) mengatakan lingkungan pengendalian berpengaruh terhadap 
kinerja karyawan sebab semakin baik lingkungan pengendalian maka akan semakin baik pula kinerja karyawan yang dihasilkan.

Adapun rumusan masalah dalam penelitian ini adalah 1) Bagaimana pengaruh Penggunaan teknologi informasi terhadap kinerja karyawan? 2) Bagaimana pengaruh Efektifitas sistem informasi akuntansi terhadap kinerja karyawan? 3) Bagaimana pengaruh Sistem pengendalian intern terhadap kinerja karyawan?

Technology Acceptance Model (TAM)dikembangkan oleh Davis (1989) dengan bersandar pada Theory of Reasoned Action (TRA).TAM berfokus pada sikap terhadap pemakai teknologi informasi, dimana pemakai mengembangkannya berdasarkan persepsi manfaat dan kemudahan dalam pemakaian teknologi infomasi. Sasaran dari TAM adalah untuk menyediakan sebuah penjelasan dari faktor-faktor penentu penerimaan komputer yang umum (Huda Agustiani, 2010). Tujuan inti dari TAM adalah untuk menyediakan sebuah gambaran yang mendasari faktor-faktor eksternal terhadap kepercayaan (belief) internal, sikap, dan tujuan.

TAM memfokuskan pada penggunaan komputer ditentukan oleh tujuan perilaku, terhadap penggunaan sistem dan perasaan kegunaan. Hubungan antara penggunaan sistem dan tujuan perilaku yang digambarkan dalam TAM menunjukkan secara tidak langsung bentuk-bentuk tujuan individu untuk melakukan tindakan yang positif. Hubungan antara perasaan kegunaan dan tujuan perilaku didasarkan pada ide bahwa dalam penyusunan organisasi, orang-orang membentuk tujuan-tujuan terhadap perilakunya yang diyakini akan meningkatkan 
Putu Diah Mirnasari dan I Made Sadha Suardhika. Pengaruh...

kinerjanya. Hal ini karena kinerja yang meningkat merupakan instrumen untuk mencapai berbagai reward yang terletak di luar pekerjaan itu sendiri, seperti peningkatan gaji dam promosi (Goodhue dan Thompson, 1995).

Pentingnya teknologi informasi sekarang ini sangat dirasakan oleh pengguna teknologi informasi di dalam suatu perusahaan terutama dalam bidang akuntansi. Peranan teknologi informasi terhadap perkembangan akuntansi yang pertama dikarenakan efisien, penghematan waktu dan biaya. Kedua karena termasuk peningkatan efektivitas untuk mencapai hasil laporan keuangan dengan benar. Ketiga untuk melindungi aset perusahaan. Manfaat teknologi informasi dalam akuntansi yaitu pekerjaan lebih mudah (makes job easier), bermanfaat untuk fungsi sistem informasi (usefull), menambah produktifitas (increase productivity), meningkatkan efektivitas (enchance effectiveness), mengembangkan kinerja pekerjaan (improve job performance).

Pemanfaatan teknologi informasi menurut Thomas et al. (1991) dalam Tjhai (2003: 3) merupakan manfaat yang diharapkan oleh pengguna sistem informasi dalam melaksanakan tugasnya atau perilaku dalam menggunakan teknologi pada saat melakukan pekerjaan. Pemanfaatan teknologi informasi yang didukung oleh keahlian personil yang mengopersikannya dapat meningkatkan kinerja perusahaan maupun individual.

Kehadiran teknologi memberikan banyak manfaat bagi perusahaan, teknologi informasi mampu meringankan aktivitas yang kompleks serta menghasilkan informasi yang dapat dipercaya, relevan, tepat waktu, lengkap, 
dapat dipahami, dan teruji dalam rangka perencanaan, pengendalian, dan pengambilan keputusan (Maharsi, 2000).

Teknologi informasi merupakan suatu kombinasi antara teknologi komputer dan teknologi komunikasi yang digunakan untuk mengolah data, termasuk memproses, menyusun, menyimpan ,memanipulasi data dengan mendalam berbagai cara untuk menghasilkan informasi yang berkualitas, yaitu informasi yang relevan, akurat dan tepat waktu, yang digunakan untuk pengambilan keputusan. Contoh dari teknologi informasi bukan hanya berupa komputer pribadi, melainkan juga telepon, peralatan rumah tangga elektronik, dan piranti genggam modern (misalnya ponsel). Pada dasarnya teknologi informasi yang merupakan bidang pengelolaan teknologi tidak terbatas pada hal-hal seperti proses, perangkat lunak komputer, sistem informasi, perangkat keras komputer, dan data konstruksi. Singkatnya, apa yang membuat data, informasi atau pengetahuan yang dirasakan dalam format visual apapun, melalui setiap mekanisme distribusi multimedia, dianggap bagian dari teknologi informasi.

Penggunaan teknologi dalam sistem informasi perusahaan hendaknya mempertimbangkan pemakai. Seiring berjalannya waktu tidak jarang ditemukan bahwa teknologi yang diterapkan dalam sistem informasi sering tidak tepat atau tidak dimanfaatkan secara maksimal oleh individu pemakai sistem informasi, sehingga sistem informasi kurang memberikan manfaat dalam meningkatkan kinerja individual. Teknologi informasi adalah faktor yang sangat mendukung dalam penerapan Sistem Infomasi yang merupakan suatu solusi perusahaan dan manajemen untuk memecahkan permasalahan manajemen yang timbul 
Putu Diah Mirnasari dan I Made Sadha Suardhika. Pengaruh...

kepermukaan.Pada era globalisasi ini para pimpinan perusahaan dalam pengambilan keputusan (Decision Making) diperlukannya Sistem Informasi yang didukung oleh Teknologi Infomasi yang tepat guna (Jumaili, 2005).

Sistem informasi akuntansi sebagai berikut: "Sistem informasi akuntansi merupakan kumpulan sumber daya yang dirancang untuk menyediakan data bagi beragam pengambil keputusan sesuai dengan kebutuhan dan kewenangan mereka" (Bodnar, George H, and S. Hopwood William, 2005). Hall (2001: 10) menyatakan sistem infomasi akuntansi terdiri dari tiga subsistem, yaitu:1) Sistem pemrosesan transaksi (transaction processing system-TPS), yang mendukung operasi bisnis harian melalui berbagai dokumen dan pean-pesan untuk para pemakai seluruh organisasi.2) Sistem pelaporan buku besar/keuangan (general ledger/financial reporting system-GL/FRS), yang menghasilkan laporan keuangan tradisional seperti laporan laba rugi, neraca, laporan arus kas, pengembalian pajak, dan laporan-laporan lainnya yang ditetapkan oleh hukum.3) Sistem pelaporan manajeman (managemen reporting system-MRS) yang menyediakan manajemen interal berbagai laporan keuangan dengan tujuan khusus dari infromasi yang diperlukan untuk pengambilan keputusan, seperti anggaran, laporan varian, dan laporan pertanggungjawaban.

Efektivitas sistem informasi akuntansi merupakan suatu keberhasilan yang dicapai oleh sistem informasi akuntansi dalam menghasilkan informasi secara tepat waktu, akurat, dan dapat dipercaya. Efektivitas sistem informasi akuntansi sangat tergantung pada keberhasilan kinerja, antara sistem pemakai (user), dan sponsor. Umumnya efektivitas sering dihubungkan dengan efisiensi dalam 
mencapai tujuan perusahaan, tujuan atau sasaran yang telah tercapai sesuai dengan rencana dapat dikatakan efektif, tetapi belum tentu efisien. Keberhasilan sistem juga tidak terlepas dari keterlibatan manajeman.

Sistem pengendalian internal pemerintah itu sendiri meliputi struktur organisasi, metode dan ukuran-ukuran yang dikoordinasikan untuk menjaga kekayaan organisasi, mengecek ketelitian dan keandalan data akuntansi, mendorong efisiensi dan mendorong dipatuhinya kebijakan manajemen (Mulyadi, 1993).

Pengendalian intern merupakan salah satu dari beberapa tipe aktivitas perencanaan dan pengendalian yang ada dalam suatu perusahaan. Setiap perusahaan memerlukan pengendalian intern, karena sistem tersebut didesain untuk mengatur aktifitas anggota organisasi melalui para pemimpin (manajer) organisasi agar sesuai dengan tujuan yang diinginkan perusahaan. Proses pengendalian dilakukan melaui para pemimpin atau manajer dengan penentuan tujuan dan strategi, pelaksanaan dan pengukuran serta analisis prestasi dan penghargaan. Selain itu pengendalian Intern juga memegang peranan penting bagi kelangsungan hidup perusahaan. Tercapainya pengendalian internal perusahaan yang baik tentu saja akan meningkatkan produktivitas serta kinerja para karyawan.

Kinerja (prestasi kerja ) adalah hasil kerja secara kualitas dan kuantitas yang dicapai oleh seseorang karyawan dalam melaksanakan tugasnya sesuai dengan tanggung jawab yang diberikan kepadanya (Mangkunegara, 2000). Kinerja adalah suatu hasil yang dicapai seseorang dalam melaksanakan tugas-tugas yang 
Putu Diah Mirnasari dan I Made Sadha Suardhika. Pengaruh...

dibebankan kepadanya yang didasarkan atas kecakapan, pengalaman, dan kesungguhan serta waktu (Hasibuan, 2002). Kinerja seseorang dikatakan baik jika orang tersebut memiliki keahlian yang tinggi, kesedian untuk bekerja, adanya imbalan/upah yang layak dan mempunyai harapan di masa yang akan datang (Mercika, 2014).

Hasil penelitian Suratini (2015) bahwa penggunaan teknologi informasi berpengaruh positif terhadap kinerja individual. Wuryaningrum (2007) menyatakan bahwa teknologi informasi yang diimplementasikan dalam organisasi seharusnya dapat memberikan manfaat pada kinerja individu dan organisasi serta memberikan kenyamanan bagi pemakainya. Menurut Handayani (2007), teknologi digunakan organisasi untuk menyediakan informasi bagi para pemakai internal dan eksternal dalam pengambilan keputusan. Teknologi informasi merupakan perpaduan antara teknologi komputer dan telekomunikasi dengan teknologi lain seperti perangkat keras, perangkat lunak, database, teknologi jaringan, dan peralatan telekomunikasi lainnya (Kurniawati, 2010).

Marlinawati (2013) mengatakan efektivitas sistem informasi akuntansi berpengaruh positif pada kinerja karyawan Lembaga Perkreditan Desa di Kabupaten Badung. Penelitian Widyasari dan Suardikha (2015) mengungkapkan bahwa efektivitas sistem informasi akuntansi berpengaruh positif terhadap kinerja individual. Tingkat efektivitas sistem informasi akuntansi yang semakin tinggi akan meningkatkan hasil kinerja individual, namun apabila efektivitas sistem informasi yang tersedia menurun maka kinerja individual yang dihasilkan akan ikut menurun. 
Pilipus Ramandei (2009) memaparkan pemahaman sistem pengendalian intern pada suatu organisasi perlu ditingkatkan agar sistem pengendalian intern organisasi perusaahaan dapat terlaksana secara efektif dan efisien dalam mencapai tingkat kinerja karyawan yang diinginkan untuk kelangsungan hidup perusahaan. Menurut Mariani (2012) mengatakan bahwa Pengendalian intern berpengaruh positif dan signifikan terhadap kinerja karyawan pada PT. Sinar Galesong Pratama Kendari. Menurut Nasir dan Ranti Oktari (2013) bahwa pengendalian intern berpengaruh signifikan terhadap kinerja Instansi Pemerintah (Studi Pada Satuan Kerja Perangkat Daerah Kabupaten Gianyar).

Berdasarkan paparan teori serta penelitian terdahulu dapat disusun hipotesis sebagai jawaban sementara pada penelitian ini sebagai berikut:

$\mathrm{H}_{1}$ :Penggunaan Teknologi Informasi berpengaruh positif terhadap Kinerja Karyawan

$\mathrm{H}_{2}$ : Efektivitas Sistem Informasi Akuntansi berpengaruh positif terhadap Kinerja Karyawan

$\mathrm{H}_{3}$ : Sistem Pengendalian Intern berpengaruh positif terhadap Kinerja Karyawan

\section{METODE PENELITIAN}

Jenis data yang digunakan dalam penelitian ini adalah data kuantitatif adalah data yang berbentuk angka-angka dan dapat diukur dengan satuan hitung (Sugiyono, 2009). Data kuantitatif dalam penelitian adalah data skor nilai dari jawaban yang telah diisi oleh responden. Data kualitatif adalah data yang berbentuk kalimat kata atau gambar (Sugiyono, 2009). Data kualitatif dalam penelitian ini adalah berupa 
Putu Diah Mirnasari dan I Made Sadha Suardhika. Pengaruh...

informasi jumlah BPR, struktur organisasi dan tugas dari masing-masing bagian dalam BPR.

Sumber data yang digunakan dalam penelitian ini adalah data primer dan data sekunder. Data primer adalah sumber data penelitian yang langsung memberikan data pada pengumpul data (Sugiyono, 2008:19).Dalam penelitian ini adalah jawaban responden dari kuesioner yang disebar. Sedangkan data sekunder adalah data penelitian yang tidak langsung memberikan data kepada pengumpul data (Sugiyono, 2008:19).Data sekunder dalam penelitian ini adalah daftar BPR di Kota Denpasar, struktur organisasi, dan penjelasan atau gambaran umum tentang instansi. Terdapat tiga variabel yang diteliti, yaitu variabel independent (bebas) dan variabel dependent (terikat). Variabel bebas adalah variabel yang memengaruhi atau yang menjadi sebab perusahaan atau timbulnya variabel terikat (Sugiyono, 2014). Variabel bebas pada penelitian ini adalah penggunaan teknologi informasi (X1), efektivitas sistem informasi akuntansi (X2), dan sistem pengendalian intern (X3).

Variabel terikat adalah variabel yang dipengaruhi atau disebut juga variabel yang menjadi akibat, karena adanya variabel bebas (Sugiyono, 2014). Variabel terikat pada penelitian ini adalah kinerja karyawan (Y).

Populasi adalah wilayah generalisasi yang terdiri atas objek atau subjek yang mempunyai kualitas dan karakteristik tertentu yang ditetapkan oleh peneliti untuk dipelajari dan kemudian ditarik kesimpulannya (Sugiyono, 2016). Populasi penelitian ini adalah BPR di Kota Denpasar yaitu berjumlah 25 unit BPR (sumber: www.bi.go.id). Sampel adalah bagian dari jumlah dan karakteristik yang 
dimiliki oleh populasi tersebut (Sugiyono, 2016). Dalam penelitian ini digunakan teknik sampling jenuh. Sampling jenuh adalah teknik penentuan sampel dengan menggunakan semua anggota populasi sebagai sampel (Sugiyono, 2016). Hal ini sering digunakan jika jumlah populasi relatif kecil atau penelitian yang ingin membuat generalisasi dengan kesalahan yang sangat kecil. Jumlah sampel yang digunakan dalam penelitian ini sebanyak 25 unit BPR.

Teknik pengumpulan data dalam penelitian ini adalah menggunakan angket (kuesioner). Kuesioner atau angket merupakan teknik pengumpulan data dengan memberikan atau menyebarkan daftar pertanyaan kepaada responden dengan harapan memberikan respons atas daftar pertanyaan tersebut. Daftar pertanyaan ini bersifat terbuka, yaitu jawaban tidak ditentukan sebelumnya oleh peneliti atau secara langsung jawaban dari responden (Juliansyah, 2011: 139). Dalam penelitian ini memakai cara observasi, kuesioner, dan wawancara. Teknik analisis data yang digunakan dalam penelitian ini, antara lain uji asumsi klasik lalu dilanjutkan dengan analisis linier berganda.

\section{HASIL DAN PEMBAHASAN}

Penelitian ini dilakukan untuk menguji pengaruh penggunaan teknologi informasi, efektivitas sistem informasi, dan sistem pengendalian intern terhadap kinerja karyawan pada Bank Perkreditan Rakyat Di Kota Denpasar. Data dikumpulkan dengan menyebarkan kuesioner ke 25 BPR yang tersebar di Kota Denpasar. 
Tabel 1.

Perincian Pengembalian dan Penggunaan Kuesioner

\begin{tabular}{lc}
\hline \multicolumn{1}{c}{ Uraian } & Jumlah Kuesioner \\
\hline Total Kuesioner yang disebar & $\mathbf{7 5}$ \\
Kuesioner yang dikembalikan & $\mathbf{7 5}$ \\
Kuesioener yang gugur & $\mathbf{0}$ \\
Kuesioner yang digunakan & $\mathbf{7 5}$ \\
Tingkat Pengembalian (response rate) $=75 / 75 \times 100 \%$ & $\mathbf{1 0 0 \%}$ \\
Tingkat Penggunaan (usable respon rate) $=75 / 75 \times 100 \%$ & $\mathbf{1 0 0 \%}$ \\
\hline Sumber: Data diolah, 2017 &
\end{tabular}

Berdasarkan Tabel 1. dapat dilihat bahwa jumlah kuesioner yang disebar sebanyak 75 eksemplar dan dapat digunakan untuk penelitian.

Tabel 2.

Karakteristik Responden

\begin{tabular}{|c|c|c|c|c|c|}
\hline No & Variabel & Klasifikasi & & Jumlah & Presentase \\
\hline \multirow[t]{3}{*}{1} & Jenis Kelamin & Perempuan & & 40 & $53 \%$ \\
\hline & & Laki-laki & & 35 & $47 \%$ \\
\hline & & & Jumlah & 75 & $100 \%$ \\
\hline \multirow[t]{3}{*}{2} & Pendidikan & D3 & & 32 & $43 \%$ \\
\hline & & $\mathrm{S} 1 / \mathrm{S} 2 / \mathrm{S} 3$ & & 43 & $57 \%$ \\
\hline & & & Jumlah & 75 & $100 \%$ \\
\hline \multirow[t]{4}{*}{3} & Masa Kerja & $<5$ tahun & & 13 & $17 \%$ \\
\hline & & 5-10 tahun & & 39 & $52 \%$ \\
\hline & & $>10$ tahun & & 23 & $31 \%$ \\
\hline & & & Jumlah & 75 & $100 \%$ \\
\hline
\end{tabular}

Sumber: Data diolah, 2017

Berdasarkan jenis kelamin responden sesuai dengan Tabel 2. diketahui bahwa dari 75 responden yang diteliti, terdapat 40 orang perempuan (53\%) dan 35 orang laki-laki (47\%). Selanjutnya diketahui bahwa responden yang pendidikan terakhirnya D3 sebanyak 32 orang (43\%) dan S1/S2/S3 sebanyak 43 orang $(57 \%)$. Dan yang terakhir yaitu masa kerja responden yang telah bekerja kurang dari 5 tahun sebanyak 13 orang (17\%), responden yang bekerja 5 sampai 10 tahun sebanyak 39(52\%), dan responden yang bekerja diatas 10 tahun sebanyak 23 orang $(31 \%)$. 
Hasil statistik deskriptif berhubungan dengan pengumpulan dan peringkat data yang menggambarkan karakteristik sampel yang digunakan dalam penelitian ini. Analisis ini berguna untuk menjelaskan karateristik sampel terutama mencakup nilai rata-rata (mean), nilai ektrim yaitu nilai minimum dan nilai maksimum, serta standar deviasi dari masing-masing variabel. Hasil dari statistik deskriptif tersebut dapat dilihat pada Tabel 3. berikut ini.

Tabel 3.

Statistik Deskriptif Variabel-Variabel Penelitian

\begin{tabular}{|c|c|c|c|c|c|}
\hline & $\mathbf{N}$ & Min & $\operatorname{Max}$ & Mean & Std. Deviation \\
\hline $\begin{array}{ll}\text { Penggunaan } & \text { Teknologi } \\
\text { Informasi }\left(\mathrm{X}_{1}\right) & \end{array}$ & 75 & 8 & 24 & 20,40 & 3,045 \\
\hline $\begin{array}{l}\text { Efektivitas Sistem Informasi } \\
\text { Akuntansi }\left(\mathrm{X}_{2}\right)\end{array}$ & 75 & 12 & 24 & 20,03 & 2,765 \\
\hline Sistem Pengendalian Intern $\left(\mathrm{X}_{3}\right)$ & 75 & 8 & 16 & 13,24 & 1,972 \\
\hline Kinerja Karyawan $(\mathrm{Y})$ & 75 & 10 & 20 & 16,72 & 2,633 \\
\hline Valid N (Listwise) & 75 & & & & \\
\hline
\end{tabular}

Statistik deskriptif pada Tabel 3. menunjukkan bahwa nilai minimum dan maksimum variabel penggunaan teknologi informasi $\left(\mathrm{X}_{1}\right)$ sebesar 8 dan 24 . Rataratanya (mean)sebesar 20,40 dengan standar deviasi sebesar 3,045, hal ini berarti bahwa terjadi penyimpangan nilai penggunaan teknologi informasi yang diteliti terhadap nilai rata-ratanya sebesar 3,045.

Nilai minimum dan maksimum variabel efektivitas sistem informasi akuntansi $\left(\mathrm{X}_{2}\right)$ sebesar 12 dan 24. Rata-ratanya (mean) sebesar 20,03 dengan standar deviasi sebesar 2,765, hal ini berarti bahwa terjadi penyimpangan nilai efektivitas sistem informasi akuntansi yang diteliti terhadap nilai rata-ratanya sebesar 2,765. 
Nilai minimum dan maksimum variabel sistem pengendalian intern $\left(\mathrm{X}_{3}\right)$ sebesar 8 dan 16. Rata-ratanya (mean)sebesar 13,24 dengan standar deviasi sebesar 1,972, hal ini berarti bahwa terjadi penyimpangan nilai sistem pengendalian intern yang diteliti terhadap nilai rata-ratanya sebesar 1,972. Nilai minimum dan maksimum variabel kinerja karyawan (Y) sebesar 10 dan 20. Rataratanya (mean)sebesar 16,72 dengan standar deviasi sebesar 2,633, hal ini berarti bahwa terjadi penyimpangan nilai kinerja karyawan yang diteliti

Pertanyaan dikatakan valid jika adanya korelasi signifikan dengan skor totalnya, hal ini menunjukkan dukungan pertanyaan tersebut dalam mengungkap suatu yang ingin diungkap. Untuk mengujinya menggunakan korelasi Pearson, yaitu dengan mengkorelasikan skor item dengan skor totalnya. Biasanya pertanyaan yang memenuhi syarat adalah jika $r=0,30$, jadi jika korelasi antara butir skor total lebih dari 0,30 maka instrumen tersebut dinyatakan valid (Sugiyono, 2014). Hasil uji validitas pada Tabel 4. menunjukkan bahwa seluruh variabel memiliki nilai koefisien korelasi dengan skor total seluruh item pernyataan lebih besar dari 0,30. Hal ini menunjukkan bahwa butir-butir pernyataan seluruhnya dalam instrumen penelitian tersebut valid.

Tabel 4.

Hasil Uji Validitas

\begin{tabular}{cclll}
\hline No & Variabel & Indikator & Koefisien Korelasi & Keterangan \\
\hline & Penggunaan Teknologi & $\mathrm{X}_{1.1}$ & 0,887 & Valid \\
& Informasi $\left(\mathrm{X}_{1}\right)$ & $\mathrm{X}_{1.2}$ & 0,874 & Valid
\end{tabular}




$\begin{array}{cccc} & \mathrm{X}_{1.3} & 0,922 & \text { Valid } \\ & \mathrm{X}_{1.4} & 0,798 & \text { Valid } \\ & \mathrm{X}_{1.5} & 0,936 & \text { Valid } \\ & \mathrm{X}_{1.6} & 0,730 & \text { Valid } \\ & \mathrm{X}_{2.1} & 0,835 & \text { Valid } \\ & \mathrm{X}_{2.2} & 0,831 & \text { Valid } \\ \text { Efektivitas Sistem Informasi } & \mathrm{X}_{2.3} & 0,847 & \text { Valid } \\ \text { Akuntansi }\left(\mathrm{X}_{2}\right) & \mathrm{X}_{2.4} & 0,850 & \text { Valid } \\ & \mathrm{X}_{2.5} & 0,835 & \text { Valid } \\ & \mathrm{X}_{2.6} & 0,864 & \text { Valid } \\ & \mathrm{X}_{3.1} & 0,930 & \text { Valid } \\ \text { Sistem Pengendalian Intern } & \mathrm{X}_{3.2} & 0,872 & \text { Valid } \\ & \mathrm{X}_{3.3} & 0,845 & \text { Valid } \\ & \mathrm{X}_{3.4} & 0,884 & \text { Valid } \\ & \mathrm{Y}_{1} & 0,947 & \text { Valid } \\ & \mathrm{Y}_{2} & 0,937 & \text { Valid } \\ \text { Kinerja Karyawan }(\mathrm{Y}) & \mathrm{Y}_{3} & 0,890 & \text { Valid } \\ & \mathrm{Y}_{4} & 0,863 & \text { Valid } \\ & \mathrm{Y}_{5} & 0,936 & \text { Valid }\end{array}$

Sumber :Data diolah, 2017

Suatu pengukur dikatakan reliabel (dapat diandalkan) jika dapat dipercaya, maka hasil dari pengukuran harus akurat dan konsisten. Dikatakan konsisten jika beberapa pengukuran terhadap subyek yang sama diperoleh hasil yang tidak berbeda (Jogiyanto,2011:120). Reliabilitas suatu variabel dilihat dari hasil statistik Croanbach Alpha (a), suatu variabel dikatakan reliabel jika memberikan nilai Croanbach alpha> 0,06 (Sugiyono, 2014).

Tabel 5. Hasil Uji Reliabilitas

\begin{tabular}{clcc}
\hline No & \multicolumn{1}{c}{ Variabel } & Cronbach's Alpha & Keterangan \\
\hline 1 & $\begin{array}{l}\text { Penggunaan Teknologi Informasi } \\
\text { (X1) }\end{array}$ & 0,929 & Reliabel \\
2 & Efektifitas Sistem Informasi & 0,917 & Reliabel \\
3 & Akuntansi (X2) & 0,902 & Reliabel \\
4 & Sistem Pengendalian Intern (X3) & 0,949 & Reliabel \\
\hline \multicolumn{2}{l}{ Kumber: (Lampiran 6) }
\end{tabular}

Hasil uji reliabilitas yang terdapat pada Tabel 5. menunjukkan bahwa seluruh intrumen penelitian memiliki Cronbach's Alphalebih dari 0,60. Hal ini 
dapat dilakukan bahwa semua intrumen reliabel sehingga layak digunakan untuk melakukan penelitian.

Agar bisa diperolehnya model regresi yang bisa dipertanggunjawabkan maka dilakukan uji normalitas,uji multikolinearitas dan uji heteroskedastisitas.Berikut ini merupakan uji asumsi klasik dalam Tabel 6.

Tabel 6.

Hasil Uji Asumsi Klasik

\begin{tabular}{lll}
\hline \multicolumn{1}{c}{ Uji Asumsi Klasik } & \multicolumn{1}{c}{ Hasil Uji } & \multicolumn{1}{c}{ Keterangan } \\
\hline Uji Normalitas & $\mathrm{p}(0,392)>0,05$ & Berdistribusi normal \\
Uji Multikolinearitas & Tolerance $(0,322) ;(0,256) ;$ & \\
& $(0,290)<0,1$ & Tidak ada multikolinearitas \\
& $\operatorname{VIF}(3,108) ;(3,902) ;$ & \\
& $(3,450)<10$ & \\
Uji Heterokedastisitas & $\mathrm{p}(0,756)>0,05 ; \mathrm{p}(0,404)>$ & Tidak terjadi \\
& 0,$05 ; \mathrm{p}(0,176)>0,05$ & heteroskedastisitas \\
\hline
\end{tabular}

Sumber: Data Diolah, 2017

Persamaan regresi linear berganda digunakan untuk mengetahui pengaruh penggunaan teknologi informasi, efektivitas sistem infomasi akuntansi, dan sistem pengendalian intern terhadap kinerja karyawan. Hasil pengujian disajikan dalam rekapitulasi hasil analisis regresi linear berganda pada tabel 7. sebagai berikut:

\section{Tabel 7.}

Rekapitulasi Hasil Analisis Regresi Linear Berganda

\begin{tabular}{|c|c|c|c|c|c|c|}
\hline \multirow[t]{3}{*}{ Model } & & \multicolumn{2}{|c|}{$\begin{array}{l}\text { Unstandardized } \\
\text { Coefficients }\end{array}$} & \multicolumn{3}{|l|}{$\begin{array}{l}\text { Standardized } \\
\text { Coefficients }\end{array}$} \\
\hline & & & Std. & & & \\
\hline & & B & Error & Beta & $\mathbf{t}$ & Sig. \\
\hline \multirow[t]{7}{*}{1} & (Constant) & $-0,628$ & 1,030 & & $-0,610$ & 0,544 \\
\hline & Pemanfaatan TI & 0,195 & 0,079 & 0,226 & 2,461 & 0,016 \\
\hline & Efektivitas SIA & 0,242 & 0,098 & 0,254 & 2,477 & 0,016 \\
\hline & Sistem PI & 0,643 & 0,129 & 0,482 & 4,985 & 0,000 \\
\hline & Adjusted $\mathrm{R}^{2}$ & & 0,800 & & & \\
\hline & $\mathrm{F}_{\text {hitung }}$ & & 99,549 & & & \\
\hline & Sig. F & & 0,000 & & & \\
\hline
\end{tabular}

Sumber :Data diolah, 2017 
Berdasarkan hasil yang diperoleh dari rekapitulasi hasil analisis regresi linear berganda berdasarkan pada hasil analisis koefisien regresi pada Tabel 4.9 adalah sebagai berikut:

$$
\mathrm{Y}=-0,628+0,195+0,242+0,643+\mathrm{e}
$$

Berdasarkan persamaan diatas, dapat dijelaskan bahwa nilai koefisien regresi variabelpenggunaan teknologiinformasi $\left(X_{1}\right)$ sebesar 0,195dapat dikatakan bahwa penggunaan teknologiinformasi $\left(\mathrm{X}_{1}\right)$ berpengaruh terhadap kinerja karawan $(\mathrm{Y})$. Sedangkan, nilai koefisien regresi yang positif menunjukkan bahwa penggunaan tenologi informasi $\left(\mathrm{X}_{1}\right)$ berpengaruh positif tehadap kinerja karyawan $(\mathrm{Y})$.

Nilai koefisien regresi efektivitas sistem informasi akuntansi (X2)sebesar0,242dapat dikatakan bahwa efektivitas sistem informasi akuntansi $\left(\mathrm{X}_{2}\right)$ berpengaruh terhadap kinerja karawan $(\mathrm{Y})$. Sedangkan, nilai koefisien regresi yang positif menunjukkan bahwa efektivitas sistem informasi akuntansi $\left(\mathrm{X}_{2}\right)$ berpengaruh positif tehadap kinerja karyawan (Y).

Nilai koefisien regresisistem pengendalian intern (X3) sebesar 0,643dapat dikatakan bahwa sistem pengendalian intern $\left(X_{3}\right)$ berpengaruh terhadap kinerja karawan (Y). Sedangkan, nilai koefisien regresi yang positif menunjukkan bahwa sistem pengendalian intern $\left(\mathrm{X}_{3}\right)$ berpengaruh positif tehadap kinerja karyawan (Y).

Uji kelayakan model dilakukan dengan uji F yang bertujuan untuk menguji apakah semua variabel bebas yang dimasukkan dalam model mempunyai pengaruh secara bersama-sama terhadap variabel dependen. Adapun hasil dari pengujian kesesuaian model dalam penelitian ini telah disajikan pada Tabel 4.9. 
Putu Diah Mirnasari dan I Made Sadha Suardhika. Pengaruh...

Berdasarkan hasil uji kesesuaian model pada Tabel 4.9di atas, dapat dilihat bahwa nilai dari uji F sebesar 99,549dan nilai p-value (Sig. F) yakni0,000lebih kecil dari nilai $\alpha=0,05$. Hal ini menunjukkan bahwa model persamaan dalam penelitian ini layak untuk digunakan.

Uji t bertujuan untuk menguji pengaruh secara parsial antara variabel bebas terhadap variabel tidak bebas dengan variabel lain dianggap konstan, dengan asumsi bahwa jika signifikansi nilai t hitung yang dapat dilihat dari analisis regresi menunjukkan kecil dari $\alpha=5 \%$ dan dapat dijelaskan bahwa berdasarkan Tabel 7. dapat dilihat bahwa tingkat signifikansi t untuk variabel Penggunaan Teknologi Informasi terhadap Kinerja Karyawan sebesar 0,016 dengan nilai koefisien beta0,195. Nilai signifikansi $t \quad 0,016<0,05$ mengindikasikan bahwa $\mathrm{H}_{1}$ diterima.Ini berarti bahwa Penggunaan Teknologi Informasi berpengaruh positif terhadap Kinerja Karyawan, sehingga hipotesis pertama dalam penelitian ini diterima. Dapat dikatakan jika semakin baikpenggunaan teknologi informasi pada BPR di Kota Denpasar,maka kinerja karyawanakan semakin meningkat, dan sebaliknya jika penggunaan teknologi informasi tidak baik, maka kinerja karyawan akan menurun.Hasil penelitian ini sejalan dengan hasil penelitian yang dilakukan olehSuratini (2015) bahwa penggunaan teknologi informasi berpengaruh positif terhadap kinerja individual. Selain hasil penelitian Suratini, hasil penelitian yang dilakukan olehKurniawati (2010) dan Handayani (2007)menyatakan bahwa teknologi informasiberpengaruh positif terhadap kinerja individu. 
Berdasarkan Tabel 7. dapat dilihat bahwa tingkat signifikansi t untuk variableEfektivitas Sistem Informasi Akuntansi terhadap Kinerja Karyawan sebesar 0,016 dengan nilai koefisien beta 0,242. Nilai signifikansi t 0,016<0,05 mengindikasikan bahwa $\mathrm{H}_{2}$ diterima.Ini berarti bahwa Efektivitas Sistem Informasi Akuntansi berpengaruh positif terhadap Kinerja Karyawan, sehingga hipotesis kedua dalam penelitian ini diterima. Dapat dikatakan jika semakin baik efektivitas sistem informasi akuntansi pada BPR di Kota Denpasar, maka kinerja karyaan akan semakin meningkat, dan sebaliknya jika efektivitas sistem informasi akuntansi tidak baik, maka kinerja karyawan akan menurun. Hasil penelitian ini sejalan dengan hasil penelitian yang dilakukan olehAditya (2013) dalam penelitiannya menunjukkan bahwa keahlian pemakai komputer dan kenyamanan fisik dan tingkat efektivitas sistem informasi akuntansi terhadap kinerja karyawan berpengaruh secara positif terhadap kinerja karyawan.Selain hasil penelitian Aditya, hasil penelitian yang dilakukan olehMarlinawati (2013) mengatakan efektivitas sistem informasi akuntansi berpengaruh positif pada kinerja karyawan Lembaga Perkreditan Desa dan penelitian yang dilakukan oleh Widyasari (2015)mengungkapkan bahwa efektivitas sistem informasi akuntansi berpengaruh positif terhadap kinerja individual.

Berdasarkan Tabel 7. dapat dilihat bahwa tingkat signifikansi t untuk variabelSistem Pengendalian Intern terhadap Kinerja Karyawan diperoleh sebesar 0,000 dengan nilai koefisien beta 0,643. Nilai signifikansi t $0,000<0,05$ mengindikasikan bahwa $\mathrm{H}_{3}$ diterima.Ini berarti bahwa Sistem Pengendalian Intern berpengaruh positif terhadap Kinerja Karyawan, sehingga hipotesis ketiga dalam 
Putu Diah Mirnasari dan I Made Sadha Suardhika. Pengaruh...

penelitian ini diterima.Dapat dikatakan jika semakin baik sistem pengendalian intern pada BPR di Kota Denpasar, maka kinerja karyaan akan semakin meningkat, dan sebaliknya jika sistem pengendalian intern tidak baik, maka kinerja karyawan akan menurun.Hasil penelitian ini sejalan dengan hasil penelitian yang dilakukan olehMariani (2012) mengatakan bahwa pengendalian intern berpengaruh positif dan signifikan terhadap kinerja karyawan pada PT. Sinar Galesong Pratama Kendari. Hasil penelitian lain yang dilakukan oleh Nasir dan Ranti Oktari (2013) bahwa pengendalian intern berpengaruh signifikan terhadap kinerja Instansi Pemerintah (Studi Pada Satuan Kerja Perangkat Daerah Kabupaten Gianyar).

Uji Koefisien Determinasi $\left(\mathrm{R}^{2}\right)$ bertujuan untuk menentukan proporsi atau presentase total variasi dalam variabel terikat yang diterangkan oleh variabel bebas secara bersama-sama.Dalam penelitian ini koefisien determinasi dilihat melalui nilai adjusted $R$ square. Adapun nilai dari adjustedR square pada penelitian ini telah disajikan pada Tabel 4.9. Berdasarkan pada Tabel 4.9diatas, dapat dilihat bahwa nilai dari adjusted $R$ square sebesar 0,800 dimana memiliki arti bahwa 80,0\% variasi kinerja karyawan dipengaruhi oleh variasi penggunaan teknologiinformasi, efektivitas sistem informasi akuntansi, dan sistem pengendalian intern. Sedangkan sisanya sebesar 20,0\% dipengaruhi oleh variabel lain diluar dari model regresi yang digunakan.

\section{SIMPULAN}

Berdasarkan hasil analisis dan pembahasan yang telah dipaparkan pada bab sebelumnya, didapatkan simpulan bahwa penggunaan teknologi informasi 
memberikan pengaruh positif terhadap kinerja karyawan pada Bank Perkreditan Rakyat di Kota Denpasar.Dengan menggunakan teknologi informasidalam menyelesaikan tugasnya sangat mendorong karyawan untuk dapat mempermudah pekerjaan dan mampu menghasilkan informasi yang tepat waktu, akurat, serta dapat dipercaya. Efektivitas sistem informasi akuntansi memberikan pengaruh positif terhadap kinerja karyawan pada Bank Perkreditan Rakyat di Kota Denpasar.Adanya sistem informasi akuntansi dapat membantu karyawan dalam mengahasilkan output dan jika hasil kegiatan semakin mendekati sasaran, berarti makin tinggi efektivitasnya. Sistem pengendalian internmemberikan pengaruh positif terhadap kinerja karyawan pada Bank Perkreditan Rakyat di Kota Denpasar. Dengan adanya pengendalian intern dapat mengurangi keumungkinan kesalahan ataupun tindakan yang tidak sesuai dengan aturan yang dilakukan oleh karyawan.Jika kesalahan yang ditemukan sedikit maka sistem pengendalian intern berhasil dilakukan.

Berdasarkan kesimpulan maka saran yang dapat disampaikan bahwa dengan adanya penggunaan teknologi informasi dan sistem informasi serta sistem pengendalian intern yang baik maka kinerja karyawan dalam suatu perusahaan akan memperoleh dampak yang positif juga bagi kelangsungan perusahaannya. Oleh karena itu diharapkan bagi perusahaan untuk menyediakan sarana komputer yang memadai serta pelatihan khusus untuk karyawannya yang tentunya sangat mempengaruhi dalam pencapaian kinerja perusahaan yang baik.

Bagi peneliti selajutnya di masa yang akan datang diharapkan lebih memperluas objek penelitian pada beberapa objek penelitian seperti kantor 
Putu Diah Mirnasari dan I Made Sadha Suardhika. Pengaruh...

pemerintahan atau yang lainnya. Hasil kuesioner merupakan data ordinal. Agar dapat diolah ke dalam model regresi, data tersebut perlu diintervalisasikan. Peneliti selanjutnya diharapkan melakukan intervalisasi data terlebih dahulu. Dan juga menambah variabel-variabel lain yang dapat berpengaruh terhadap kinerja karyawan seperti kesesuaian tugas, kondisi yang memfasilitasi, kepuasan pengguna, dan prosedur pengendalian sehingga hasil penelitiannya dapat digeneralisasikan untuk penelitian lain yang sejenis.

\section{REFERENSI}

AA. Anwar Prabu Mangkunegara, 2000. Manajemen Sumber Daya Manusia Perusahaan. Bandung : PT Remaja Rosdakarya.

AA. Prabu Mangkunegara, 2008. Manajemen Sumber Daya Manusia Perusahaan. Remaja Rosdakarya, Bandung.

Aditya Puja, Pratama. G. dan Suardikha. 2013. Keahlian Pemakai Komputer Dan Kenyamanan Fisik Memoderasi Pengaruh Efektivitas Sistem Informasi Akuntansi terhadap Kinerja Karyawan di PT Bank Sinar Harapan Bali Denpasar. EjournalAkuntansi, Universitas Udayana, Vol.5, No.2, hal 361-381

Bodnar, George HI willian S. Hopwood, 2005. Accounting Information System, Sevent Edition, USA.

Bodnar, George H, and William S.Hopwood. 2006. Sistem Informasi Akuntansi, Buku I. Jakarta: Penerbit salemba empat.

Chau, Patrick Y. K dan Hu, Paul J. (2002). Examining a Model of Information technology Acceptence by Individual Professionals: An Exploratory Study [electronic version]. Journal of Management Information System, Vol 18, No 4, pg 191-229.

Ghozali, Imam. 2016. Aplikasi Analisis Multivariate Dengan Program IBM SPSS 23. Semarang: Badan Penerbit Universitas Diponogoro

Gibson, James .L. 1997. Manajemen. Alih bahasa Zuhad Ichyandin : Ed 9. Jakarta : Erlangga. 
Jumaili, Salman. 2005. Kepercayaan Terhadap Teknologi Sistem Informasi Baru Dalam Evaluasi Kinerja Individual. SimposiumNasional Akuntansi VIII, Solo

Lasso, Ananta Budi. 2016. Pengaruh Pengendalin Intern Terhadap Kinerja Karyawan Bagian Produksi PT.Brother Silver. Jurnal Ilmu dan Riset Akuntansi Vol 5, No 11.

Marlinawati, Ni Made Ayu dan Suarnaya. 2013. Pengaruh Penggunaan Teknologi Akuntasi, Efektivitas Sistem Informasi Akuntansi, Kepercayaan Sistem Informasi Akuntansi, dan Kesesuaian Tugas pada Kinerja Karyawan LPD di Kabupaten Badung. E-journalAkuntansi,Universitas Udayana Vol 2, No.2, hal 1-14

Mahendra, A. Reza, dan Affandy. D. Poernawan. 2013. Faktor-Faktor Yang Mempengaruhi Minat Pemanfaatan Sistem Informasi Pengelolaan Keuangan Daerah (SIPKD): Studi kasus pada Pemerintahan Kota Blitar. Jurnal Akuntansi Fakultas Ekonomi Universitas Brawijaya, Vol 10, No 1, Hal: 1-23.

Mudjiati, J. 2008. Studi Pengaruh Penggunaan Sistem Informasi Terhadap Kinerja Karyawan Fakultas Ekonomi Universitas Diponegoro Semarang.Tesis. Semarang: Universitas Diponegoro.

Mulyadi. 1993. Sistem Akuntansi. Edisi 3. Yogyakarta: Bagian Penerbit Sekolah Tinggi Ilmu Ekonomi YKPN.

Mulyadi, 2001, Sistem Akuntansi, Edisi Ketiga, Cetakan Ketiga, Penerbit Salemba Empat, Jakarta.

Maharsi, Sri. 2000. "Pengaruh Perkembangan TI Terhadap Bidang Akuntansi Manajemen”. Jurnal Akuntansi dan keuangan”. Vol 2 No 2 .November. Hal 127-137

Mercika, Dewi Tresna dan Jati, I Ketut. 2014. Kemudahan Penggunaan Sebagai Pemoderasi Pengaruh Efektivitas Sistem Informasi Akuntansi Terhadap Kinerja Karyawan. Skripsi Fakultas ekonomi Universitas Udayana.

Nasir, Azwir dan Oktari Ranti.2013. Pengaruh Pemanfaatan Teknologi Informasi Dan Pengendalian Intern Terhadap Kinerja Instansi Pemerintah (Studi Pada Satuan Kerja Perangkat Daerah Kabupaten Kampar). Jurnal Akuntansi, Universitas Riau, Vol.19, No.02, hal 1-14

Njeri, Kamau Caroline. 2014. Effect of Internal Controls on the Financial Performance of Manufacturing Firms in Kenya. Thesis. University of Nairobi. 
Putu Diah Mirnasari dan I Made Sadha Suardhika. Pengaruh...

Salehi, Mahdi; Rostami Vahab; Mogadam Abdolkarim. 2010. Usefulness of Accounting Information System in Emerging Economy: Empirical Evidence of Iran. International Journal of Economics and Finance. pp: 186-195.

Sugiyono. 2008. Metode Penelitian Bisnis, ed. Revisi, Cetakan Delapan Belas, CV. Alafabetha, Bandung

Sugiyono. 2009. Metode Penelitian Kuantitatif dan Kualitatif. CV. Alfabeta: Bandung.

Sugiyono. 2013. Metode Penelitian Pendidikan Pendekatan Kuantitatif, Kualitatif dan $R \& D$. Bandung: ALFABETA

Sugiyono. 2014. Metode Penelitian Kuantitatif Kualitatif dan R\&D. Bandung : Alfabeta.

Sugiyono. 2011. Metode Penelitian Pendidikan (Pendekatan Kuantitatif, Kualitatif, dan $R \& D)$. Bandung: Alfabeta.

Sugiyono. 2016. Metode Penelitian Pendidikan (Pendekatan Kuantitatif, Kualitatif, dan $R \& D)$ ). Bandung: Alfabeta.

Simamora, Henry. 2004. Manajemen Sumber Daya Manusia. Edisi I. Cetakan Pertama. Yogyakarta: STIE YKPN Yogyakarta.

Suratini, Eka, dkk. 2015. Pengaruh Efektivitas Sistem Informasi Akuntansi Dan Penggunaan Teknologi Informasi Akuntansi terhadap Kinerja Individual Pada PT. Bank Pembangunan Daerah Bali Kantor Cabang Singaraja. JurnalAkuntansi Program S1, Universitas Pendidikan Ganesha, Vol 3, No.1, hal 1-10

Sugiartini, Ni Made. 2016. Pengaruh Efektivitas Teknologi Sistem Infomasi Akuntansi Pada Kinerja Individu Dengan Budaya rganisasi Sebagai Pemoderasi. E-journalAkuntansi,Universitas Udayana, hal 1867-1894

Tjhai, Fung Jin. 2003. Analisis Faktor-faktor yang Mempengaruhi Pemanfaatan Teknologi Informasi dan Pengaruh Pemanfaatan Teknologi Informasi terhadap Kinerja Akuntan Publik. Jurnal Bisnis dan Akuntansi, Vol.5, No.1, hal 1-26 